JOURNAL OF ISLAMIC EDUCATION

Vol. 6 No. I May 202 I

P-ISSN 2503-5363; E-ISSN 2528-0465

http://www.ejournal.stitmuhbangil.ac.id/index.php/jie

\title{
Upaya Peningkatan Motivasi Belajar Baca Qur'an Melalui Learning Together Technique of Cooperative Learning Method
}

\author{
Ratna Untari \\ (SMK Negeri 1 Mlarak, Jalan Raya Mlarak, Ponorogo) \\ ratna.un1970@gmail.com
}

\begin{tabular}{|c|c|}
\hline Informasi Artikel & Abstract \\
\hline $\begin{array}{l}\text { Received: } \\
\text { 14 December } 2020 \\
\text { Accepted: } \\
25 \text { Maret } 2021 \\
\\
\text { Published: } \\
2 \text { May } 2021 \\
\text { Keywords: } \\
\text { Learning Motivation, } \\
\text { Reading al-Qur'an, } \\
\text { Learning Together } \\
\text { Technique, } \\
\text { Cooperative Learning } \\
\text { Method }\end{array}$ & $\begin{array}{l}\text { This study aims to describe and analyze in-depth } \\
\text { the efforts to improve the learning motivation of } \\
\text { reading al-Qur'an of students in class XI } \\
\text { Multimedia by learning together techniques of } \\
\text { cooperative learning methods at SMK Negeri } 1 \\
\text { Mlarak Ponorogo. The research approach used } \\
\text { was a classroom action research model of Kemmis } \\
\text { and Taggart in the form of a spiral consisting of } \\
\text { three cycles. Each cycle consists of planning, } \\
\text { action, observation, and reflection. Data collection } \\
\text { techniques used written and oral tests, } \\
\text { observation, and audio recordings. Then, the } \\
\text { research data will be analyzed by data reduction, } \\
\text { data display, and conclusions. This study } \\
\text { proposes the findings that: learning together } \\
\text { technique of cooperative learning method has a } \\
\text { positive impact in increasing the motivation to } \\
\text { learn to read al-Qur'an students of class XI } \\
\text { Multimedia at SMK Negeri } 1 \text { Mlarak Ponorogo. } \\
\text { This is indicated by the increase in student } \\
\text { learning completeness in each cycle, namely: } \\
\text { cycle } 1 \text { (41.93\%), cycle II (67.74\%), cycle III } \\
\text { (100\%). In addition, the learning together } \\
\text { technique of cooperative learning method makes } \\
\text { students feel that they get attention and the } \\
\text { opportunity to convey opinions or ideas and } \\
\text { questions related to reading the al-Qur'an. The } \\
\text { application of learning together techniques of } \\
\text { cooperative learning methods has a positive effect } \\
\text { in increasing student motivation in reading al- } \\
\text { Qur'an. }\end{array}$ \\
\hline
\end{tabular}




\section{PENDAHULUAN}

Pada akhir-akhir ini, tak sedikit peristiwa yang mengkhawatirkan bagi umat Islam, terhadap kesucian kitab suci umat Muslim, yaitu al-Qur'an (Sumaryanti, Syam, \& Syukroni, 2020), baik dari segi pelecehan secara fisik, seperti halnya yang terjadi di sel penjara Guantanamo (Rochelle, 2019), multi tafsir yang dilakukan secara liberal tanpa kendali (Andini, 2019), pendangkalan nilai-nilai yang terkandung didalamnya, maupun hujatan terhadap keabsahan atas kesucian al-Qur'an itu sendiri. Tentu saja hal tersebut sangat amat meresahkan, karena telah mengusik dasar keyakinan umat Islam secara luas. Al-Qur'an merupakan sumber pokok dan utama dari seluruh ajarah Islam yang diturunkan oleh Allah SWT kepada Nabi Muhammad SAW; pedoman hidup utama bagi umat Muslim (Laila, 2014); dan pedoman dalam mencapai kebahagiaan hidup didunia dan akhirat bagi seluruh umat Mulsim di dunia (Ikhwan, Farid, Rohmad, \& Syam, 2020). Sejak awal diturunkannya dan hingga saat ini, al-Qur'an senantiasa dipelihara oleh Allah SWT, sehingga terjamin otentitasnya dan terjaga dari upaya tangan kotor yang hendak mengubah dan merusaknya.

Menurut Muhammad (2019), kemurnian dan keaslian teks al-Qur'an tidak perlu diresahkan. Sebab, kepastian dan kebenarannya sudah teruji oleh sejarah. Sehingga sampai kini sudah terbukti bahwa al-Qur'an tetap terjaga keasliannya. Teks al-Qur'an itu sudah aman dan tak ada pemalsuan didalamnya. Tak akan ada campur tangan manusia untuk melakukan intervensi terhadap teks al-Qur'an (Masruroh, 2018). Hasil penelitian Laila (2014) dan Jaya (2019), juga menunjukkan bahwa apabila ada yang berusaha untuk memberikan penafsiran yang condong menodai kesucian al-Qur'an, maka penodaan atas kesucian tersebut, akan terbantahkan sendiri oleh al-Qur'an. Hal ini terbukti bahwa satu-satunya kitab suci yang masih utuh bacaannya, bunyinya, kata-katanya belum tergantikan, masih utuh keasliannya dan dihafal oleh banyak orang adalah al-Qur'an (Mujiono, Kurnianto, \& Setiawan, 2017). 
Bagaimana pun orang berusaha merusak al-Qur'an, al-Qur'an tetap saja utuh kemurniannya (Hitami, 2012). Konsep al-Qur'an itu tetap abadi sampai hari kiamat. Tidak lapuk dimakan zaman, tidak usang diserang orang.

Kaum muslim sangat menyakini bahwa al-Qur'an merupakan petunjuk, pengarah, rahmat, dan wahyu dari Allah SWT bagi seluruh umat Muslim, serta berlaku sepanjang waktu dan zaman (Ikhwan, Noh, \& Iman, 2020). Sekalipun masyarakat terus menerus berubah dan zaman terus silih berganti, namun alQur'an tidak pernah sedikitpun mengalami perubahan dan al-Qur'an memang tidak pernah berubah sama sekali, serta tidak pernah direvisi sepatah katapun oleh kaum Muslim (Ikhwan, 2016). Seluruh ayat yang ter-maktub dalam alQur'an bersifat potensial dan akan berlaku sepanjang kehidupan manusia di dunia (Jaya, 2019). Nilai dan norma yang terkandung dalam al-Qur'an akan terus berlangsung abadi, karena telah sejalan dengan fitrah penciptaaan manusia di dunia ini (Ikhwan, 2014). Selain itu, al-Qur'an juga mempunyai gaya bahasa bernilai tinggi, dan bahasa balaghah yang dapat mempengaruhi jiwa pembaca dan pendengarnya (Ashari, 2017; Ashari, Syam, \& Budiman, 2017); mempunyai kata-kata yang mempesona dan mengagumkan, serta memiliki keunikan dan keistimewaan dalam setiap susunan kata-katanya (Yanggo, 2018); dan al-Qur'an mengandung kemukjizatan dan ketinggian sastra, dimana setiap bahasa yang tertuliskan dalam al-Qur'an dapat dijadikan ibrah yang sempurna dan menggembirakan hati, baik pada zaman Rasullullah SAW, maupun pada masa-masa sesudahnya.

Tony Blair, mantan Perdana Menteri Inggris, mengemukakan bahwa setiap harinya ia membaca al-Qur'an. Walaupun beliau bukanlah seorang Muslim, namun baginya membaca al-Qur'an dapat memberikan pengetahuan tentang apa yang terjadi di dunia dan kandungan isi al-Qur'an dapat memberikannya suatu pelajaran dan hikmah yang sangat berharga bagi dirinya. Selain itu juga, beliau sangat memuji al-Qur'an sebagai kitab suci reformasi. Menurutnya, alQur'an mengajarkan kepada setiap manusia untuk mengutamakan ilmu 
pengetahuan dan membenci tahayul. Tony Blair juga mengemukakan bahwa alQur'an setidaknya memiliki terdapat dua sifat fundamental, yaitu pertama, alQur'an sifat inklusif, dimana al-Qur'an sangat mendorong kemajuan dan perkembangan ilmu pengetahuan dan menyampingkan segala sesuatu yang berbentuk tahayul; dan kedua, al-Qur'an juga bersifat praktis, dimana al-Qur'an jauh lebih maju dari zamannya, terutama dalam hal pernikahan, perempuan, dan pemerintahan (Anwar, 2021).

Oleh karena pentingnya memahami dan membaca al-Qur'an sebagaimana yang telah dijelaskan diatas, maka peningkatan baca al-Qur'an harus terus dilakukan terhadap generasi muda islam, terlebih dikalangan siswa SMK, karena mereka rata-rata sudah memasuki usia dewasa (Husna, Jalil, \& Dewi, 2020). Apalagi dalam realitas sosial telah terlihat banyaknya para siswa SMK pada umumnya masih belum memiliki kemampuan yang baik dalam membaca alQur'an. Hal ini terlihat dari minimnya pengetahuan mereka tentang pentingnya membaca al-Qur'an dalam kehidupan sehari-hari (Arsyad \& Salahudin, 2018); siswa SMK masih kurang percaya diri dengan kemampuan bacaan al-Qur'an yang dimilikinya (Syam, Ulfatin, \& Maisyaroh, 2020); pembinaan dan perhatian keluarga atau orang tua masih kurang maksimal dalam mengingatkan siswa untuk membaca al-Qur'an (Dalimunthe, 2020); dan lingkungan pergaulan mereka yang kurang mendukung (Aryati, Azizah, \& Hazmin, 2020). Sementara itu, kesempatan dan waktu yang tersedia di sekolah masih sangat terlalu minim dalam memaksimalkan pembinaan bagi siswanya (Budiman, 2017; Syam, Supriyanto, \& Mustiningsih, 2020).

Berdasarkan hal diatas, maka perlu adanya terobosan-terobosan baru bagi para guru agama untuk memaksimalkan pembinaan agama di sekolah melalui learning together technique of cooperative learning method, khususnya berkaitan dalam meningkatkan baca al-Qur'an siswanya, misalnya membuat kelompok-kelompok kecil dalam mempelajari baca al-Qur'an bagi siswa yang tidak mampu dengan didampingi oleh guru agama ataupun didampingi siswa 
yang telah memiliki bacaan al-Qur'an yang baik (Syam \& Mukhlas, 2019). Pembinaan ini, bertujuan untuk memotivasi dan meningkatkan kemampuan baca al-Qur'an siswa (Ikhwan, Noh, et al., 2020). Selain itu, materi membaca al-Qur'an dapat menjadi syarat utama untuk siswa mempelajari pendidikan agama Islam dengan mewajibkan mereka untuk memiliki kemampuan membaca al-Qur'an yang sesuai dengan kaidah ilmu tajwidnya (Hidayat \& Syam, 2020; Husna et al., 2020). Selain itu, usaha untuk meningkatkan kemampuan bacaan al-Qur'an siswa tersebut, juga dapat dilakukan dengan meningkatkan proses pembelajaran al-Qur'an melalui tiga tahapan, yaitu tahap pra-membaca, tahap saat membaca dan tahap pasca-membaca (Maghfiroh, Sholikhah, \& Sofyan, 2019). Ketekunan siswa dalam mengikuti proses pembelajaran akan mempermudah guru agama untuk mengetahui permasalahan siswa dalam membaca ayat al-Qur'an, baik dari segi bacaannya ataupun tajwidnya. Atas dasar kenyataan inilah, peneliti tertarik untuk melakukan penelitian lebih lanjut tentang upaya peningkatan motivasi belajar baca al-Qur'an siswa kelas XI Multimedia dengan learning together technique of cooperative learning method di SMK Negeri 1 Mlarak Ponorogo.

\section{METODE PENELITIAN}

Penelitian ini bertujuan untuk mendeksripsikan dan menganalisis secara mendalam tentang upaya peningkatan prestasi belajar baca al-Qur'an siswa kelas XI Multimedia dengan learning together technique of cooperative learning method di SMK Negeri 1 Mlarak Ponorogo. Pendekatan penelitian yang digunakan adalah penelitian tindakan kelas (action research), karena penelitian ini dilakukan untuk memecahkan masalah pembelajaran, menggambarkan bagaimana teknik pembelajaran diterapkan dan menggambarkan hasil pembelajaran yang diinginkan dapat tercapai dengan baik (Khasinah, 2013). Model penelitian tindakan kelas yang digunakan adalah penelitian tindakan kelas model Kemmis et al. (2013), yaitu penelitian tindakan dalam bentuk 
spiral, dan terdiri dari tiga siklus. Setiap siklus tersebut, terdiri dari planning (rencana), action (tindakan), observasion (pengamatan), dan reflection (refleksi). Namun, sebelum masuk pada siklus satu dilakukan tindakan pendahuluan yang berupa identifikasi permasalahan. Adapun tahapan-tahapan siklus dalam penelitian tindakan kelas model Kemmis dan Taggart Siklus dapat digambarkan pada gambar berikut:

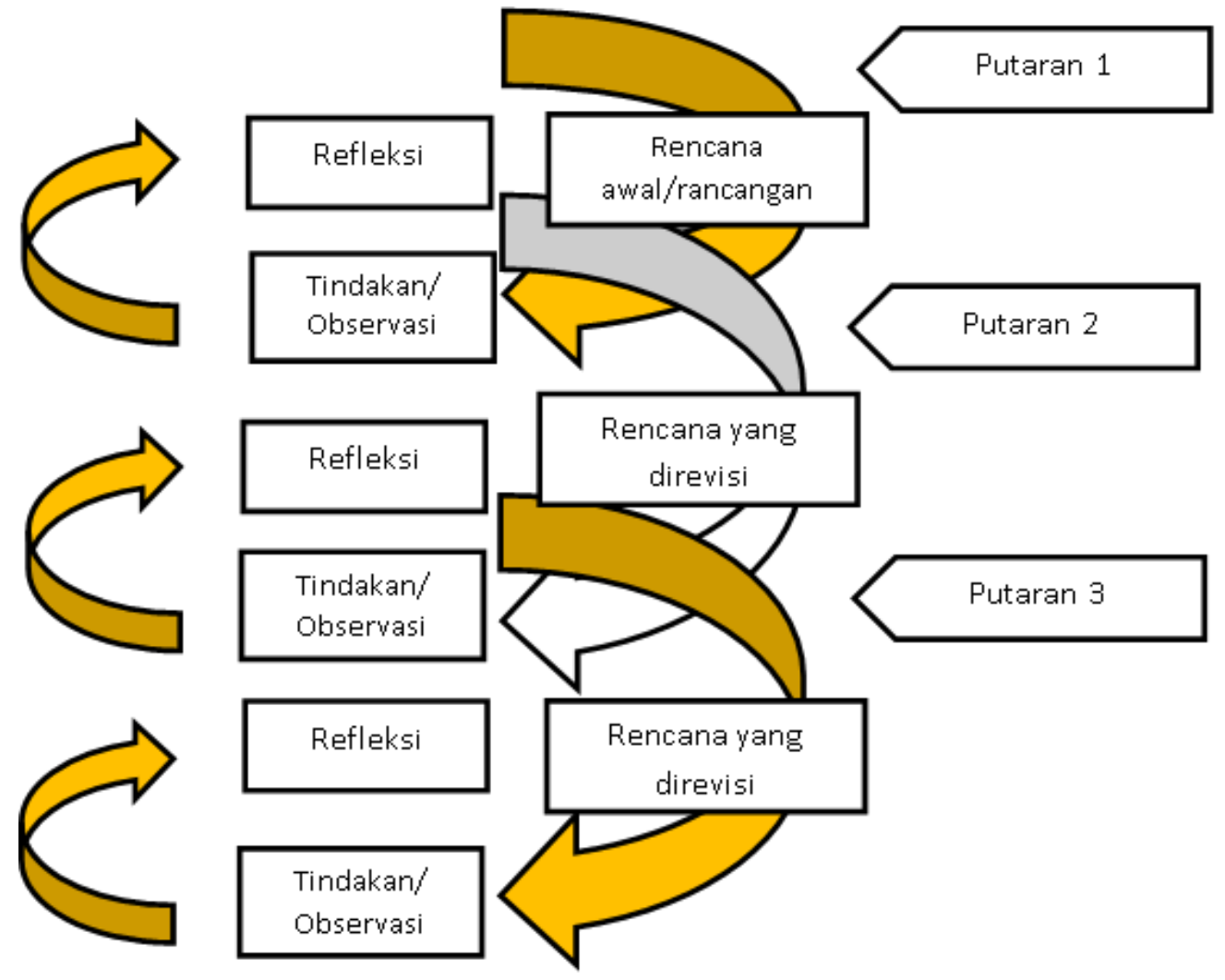

Gambar 1. Tahapan Siklus Penelitian Tindakan Kelas

Teknik pengumpulan data yang digunakan dalam penelitian ini terdiri dari: tes yang dibuat oleh guru, metode observasi, dan dokumentasi dalam bentuk rekaman audio (Ghony, 2008). Kemudian, data penelitian akan dianalisis dengan model analisis data Huberman \& Miles (2002) yang terdiri dari reduksi data (memilah data penting, relevan, dan bermakna dari data yang tidak berguna), penyajian data (narasi, visual gambar, tabel) dengan alur sajian yang sistematis dan logis, penyimpulan dari hasil yg disajikan.

\section{TEMUAN DAN PEMBAHASAN}


Siklus pertama dilaksanakan tanggal 19 Agustus 2020. Peneliti mencoba dengan menerapkan metode membaca al-Qur'an dengan learning together pada siswa kelas XI Multimedia di SMK Negeri 1 Mlarak Ponorogo dengan harapan sistem pembelajaran ini dapat meningkatkan motivasi belajar siswa dalam membaca al-Qura'n dan nantinya dapat berdampak pula pada prestasi belajar mereka.

\section{Deskripsi Siklus Pertama}

Sebelum pelajaran dimulai guru menyiapkan materi pelajaran siswa menempati tempat duduk yang disediakan. setelah pelajaran dimulai, guru mengenalkan materi membaca al-Qur'an pada surat al-Maidah ayat:48, surat an-Nisa' ayat:59, dan surat At Taubah ayat:105. Pada kegiatan ini, guru memberikan contoh membaca yang lancar, benar tartil, dan fase selanjutnya siswa menirukan secara bergantian. Guru memberi pengarahan tentang tata cara membaca al-Qur'an berdasarkan tajwid. Pelaksanaan membaca dilaksanakan dalam kelas, selanjutnya guru memberi tugas untuk membaca yang lain menyimak dan selanjutnya diskusi kelompok, bila sudah selesai perwakilan kelompok maju ke depan dengan mempresentasikan hasilnya, siswa dibagi 10 kelompok setiap kelompok 3-4 siswa pembagian berdasarkan nomor urut absen dan sesuai jenis kelamin. Selanjutnya guru memberi tugas perorangan, dan diakhiri pelajaran guru menyimpulkan dan menilai prestasi belajar siswa.

Pelaksanaan siklus pertama berjalan sesuai rencana pelajaran dimulai berdoa dan mengucapkan salam dan mengecek daftar hadir siswa. Kemudian mengkondisikan siswa siap menerima pelajaran dan mengamati siswa dengan menggunakan lembar observasi yang disiapkan. Sebelum melakukan kegiatan inti peneliti memberi apersepsi materi yang diajarkan menjelaskan bacaan dari al-Qur'an surat al-Maidah ayat:48, surat an-Nisa' ayat:59, dan surat At Taubah ayat:105, siswa memperhatikan mendengarkan dan menirukan titik selanjutnya peneliti mengevaluasi kemampuan pembacaan dan pengetahuan siswa. 


\section{Analisa Siklus Pertama}

Berdasarkan data yang diperoleh dari lembar observasi catatan lapangan dan wawancara terdapat beberapa teman-teman sebagai pertimbangan. Temuan pertama: siswa masih sulit dalam mengkondisikan kelas, masih banyak siswa yang masih kelihatan bingung ketika belajar membaca surat al-Qur'an secara perorangan dan diskusi kelompok. Temuan kedua: siswa masih kurang dalam penguasaan materi hal ini tampak ketika siswa menerangkan kembali dalam kelompoknya dan masih ragu-ragu dalam menyampaikan pada temannya. Temuan ketiga, ketika berdiskusi dengan teman sekelompoknya siswa tampak terlihat masih kaku. Temuan keempat, kerja perorangan maupun kelompok masing-masing siswa masih kurang.

\section{Refleksi Siklus Pertama}

Hasil dari analisis siklus pertama siswa masih banyak yang kesulitan karena kurang memperhatikan contoh bacaan, dan dalam mengorganisasikan antar siswa dalam satu kelompok siswa masih belum bisa menyesuaikan titik karena ada materi yang ditetapkan guru menjadi penguasaan materi masih kurang maksimal dan tidak memberdayakan alat bantu yang ada titik untuk menindaklanjuti siklus berikutnya peneliti akan memantapkan learning together technique of cooperative learning method dengan menggabungkan metode yang lain.

Siklus kedua dilaksanakan tanggal 26 Agustus 2020. Peneliti mencoba untuk memantapkan lagi dengan menerapkan learning together technique of cooperative learning method pada siswa kelas XI Multimedia SMK Negeri 1 Mlarak Ponorogo.

\section{Deskripsi siklus kedua dilaksanakan dalam bahasa}

Seperti biasa guru menyiapkan materi yang akan dipelajari sesuai titik guru mengkondisikan ruang laboratorium/kelas dengan learning together technique of cooperative learning method. Mulai pelajaran terlebih dahulu guru menerangkan bagaimana cara mengucapkan bacaan dengan lancar benar, 
tartil, dan fasih. guru memberi tugas membaca pada siswa, sedangkan yang lain menyimak. Selanjutnya guru membagi menjadi 10 kelompok setiap kelompok 3-4 siswa dengan pembagian kelompok berdasarkan tempat duduk siswa yang berdekatan sesuai dengan jenis kelamin siswa. Berikutnya kelompok siswa yang mengerjakan tugas secara kelompok tetapi laporan dan tanggung jawab secara individu selanjutnya dari perwakilan kelompok untuk mempresentasikan secara bergantian di depan kelas. Akhir pembelajaran guru menyimpulkan materi pembelajaran yang diberikan dan guru menilai pada siswa atau kelompok siswa.

Pelaksanaan siklus kedua dengan pembukaan dan mengkondisikan agar siswa siap menerima pelajaran titik sebelum kegiatan inti berdoa mengucapkan salam dan mengajak kehadiran. Kemudian mengkondisikan sesuai siap menerima pelajaran dan pengamatan siswa secara individu atau kelompok. menjelaskan fungsi masing-masing. Selanjutnya observer menyuruh pada siswa untuk mengerjakan tugas menjawab pertanyaan tentang tajwid surat Al-Isra', ayat: 26-27, selanjutnya siswa diberi tugas pekerjaan oleh guru supaya dikerjakan secara individu untuk mengetahui prestasi belajar siswa.

\section{Analisis siklus kedua}

Berdasarkan data yang diperoleh dari lembar observasi dan wawancara terhadap beberapa temuan sebagai pertimbangan selanjutnya. Temuan pertama: siswa terlihat mulai bisa mengkondisikan dalam menerima materi pelajaran. Temuan kedua: siswa kurang memanfaatkan media pembelajaran dalam kegiatan diskusi kelompok dalam mengerjakan tugas. Temuan ketiga: siswa sudah mampu menerima materi dengan baik dan sudah mulai dapat bekerjasama dengan baik dalam mengerjakan tugas.

\section{Refleksi siklus kedua}


Hasil analisis dalam siklus kedua diperoleh data bahwa penerapan model learning together sebagian besar sudah dipahami oleh siswa. Aktivitas dan kreativitas data kelompok masih belum optimal namun sudah banyak siswa yang aktif. Maka peneliti mencoba untuk memantapkan lagi kooperatif model learning together untuk siklus III supaya prestasi belajar lebih meningkat.

Siklus ketiga ini dilaksanakan pada tanggal 2 September 2020. Peneliti mencoba untuk memantapkan lagi dengan menggunakan learning together technique of cooperative learning method pada siswa kelas XI Multimedia SMK Negeri 1 Mlarak Ponorogo.

\section{Perencanaan siklus ketiga}

Perencanaan siklus ketiga ini dilaksanakan pada pertemuan tanggal 2 September 2020. Sebelum pelajaran dimulai guru menyiapkan materi yang akan dipelajari siswa guru mengkondisikan ruang laboratorium untuk pembelajaran materi membaca al-Qur'an surat Al-Isra' ayat 26-27. Mulai pelajaran terlebih dahulu guru mengenalkan pokok bahasan materi pelajaran selanjutnya guru menyuruh siswa untuk membaca secara bergantian secara benar, lancar, tartil, dan fasih selanjutnya siswa yang lain menyimak. Selanjutnya diskusi dibagi menjadi 10 kelompok kelompok 3-4 siswa pembagian berdasarkan hasil prestasi belajar dan jenis kelamin sama. Selanjutnya masingmasing perwakilan kelompok siswa untuk mempresentasikan secara bergantian di depan kelas dengan pembagian materi berbeda titik akhir pembelajaran guru menyimpulkan materi pelajaran yang diberikan, dan guru menilai prestasi belajar pada siswa atau kelompok siswa.

\section{Pelaksanaan siklus ketiga}

Pelaksanaan siklus ketiga ini, dilaksanakan sebelumnya siswa berdoa mengucapkan salam dan mengisi daftar hadir. Selanjutnya melakukan pekerjaan ini yaitu menerima materi pelajaran, siswa diberi penjelasan pembelajaran yang disampaikan. Setelah itu peneliti memberi latihan membaca ayat al-Qur'an Untuk persepsi terhadap materi yang diberikan titik peneliti 
memberi penjelasan tentang cara membaca surat al-Maidah ayat:48, surat anNisa' ayat:59, dan surat At Taubah ayat:105. Selanjutnya siswa diberi evaluasi untuk mengetahui hasil evaluasi belajar secara lisan untuk mengingat kembali materi yang diberikan, dan juga diberi tugas pekerjaan untuk mengetahui keberhasilan prestasi belajar siswa.

\section{Analisis siklus ketiga}

Berdasarkan data yang diperoleh dari lembar observasi catatan lapangan dan wawancara terdapat beberapa temuan sebagai pertimbangan selanjutnya. Temuan pertama: sesuatu tanpa memahami dan mengerti dengan pembelajaran learning together technique of cooperative learning method. Temuan kedua: penguasaan materi yang diberikan pada siswa lebih baik. Temuan ketiga: komunikasi siswa dalam kelompok menjadi baik; dalam mengerjakan tugas menjadi efektif.

\section{Refleksi siklus ketiga}

Hasil analisis dalam siklus III diperoleh data bahwa penerapan model learning together sudah dipahami oleh setiap siswa. Aktivitas dan kreativitas dalam kelompok sudah optimal. Prestasi siswa dalam membaca dan pengetahuan surat al-isra meningkat maka peneliti mencoba untuk memantapkan modal menurut Carter dan menggabungkan dengan metode lain guna untuk meningkatkan prestasi belajar membaca dan pengetahuan siswa.

Hasil partisipasi siswa dalam kegiatan KBM pada siklus pertama, kedua, dan ketiga siswa kelas XI Multimedia SMK Negeri 1 Mlarak Ponorogo dinyatakan dalam tabulasi data sebagai berikut:

Tabel 1. Partisipasi Siswa Dalam Kegiatan Belajar Membaca al-Qur'an

Siswa Kelas XI Multimedia SMK Negeri 1 Mlarak Ponorogo

\begin{tabular}{|c|c|c|c|l|l|l|}
\hline \multirow{2}{*}{ Partisipasi } & \multicolumn{2}{|c|}{ Siklus I } & \multicolumn{2}{c|}{ Siklus II } & \multicolumn{2}{c|}{ Silkus III } \\
\cline { 2 - 5 } Siswa & $\begin{array}{c}\text { Jumlah } \\
\text { siswa }\end{array}$ & Prosentase & $\begin{array}{c}\text { Jumlah } \\
\text { siswa }\end{array}$ & Prosentase & $\begin{array}{c}\text { Jumlah } \\
\text { siswa }\end{array}$ & Prosentase \\
\hline
\end{tabular}




\begin{tabular}{|l|c|c|c|c|c|c|}
\hline Aktif & 14 & $45,16 \%$ & 20 & $64,52 \%$ & 31 & $100,0 \%$ \\
\hline Kurang Aktif & 9 & $29,04 \%$ & 8 & $25,80 \%$ & 0 & $0,0 \%$ \\
\hline Tidak Aktif & 8 & $25,80 \%$ & 3 & $9,68 \%$ & 0 & $0,0 \%$ \\
\hline \multicolumn{1}{|c|}{ Jumlah Siswa } & 31 & $100 \%$ & 31 & $100 \%$ & 31 & $100 \%$ \\
\hline
\end{tabular}

Grafik 1. Partisipasi Siswa Dalam Kegiatan Belajar Membaca al-Qur'an Pada Siswa Kelas XI Multimedia di SMK Negeri 1 Mlarak Ponorogo

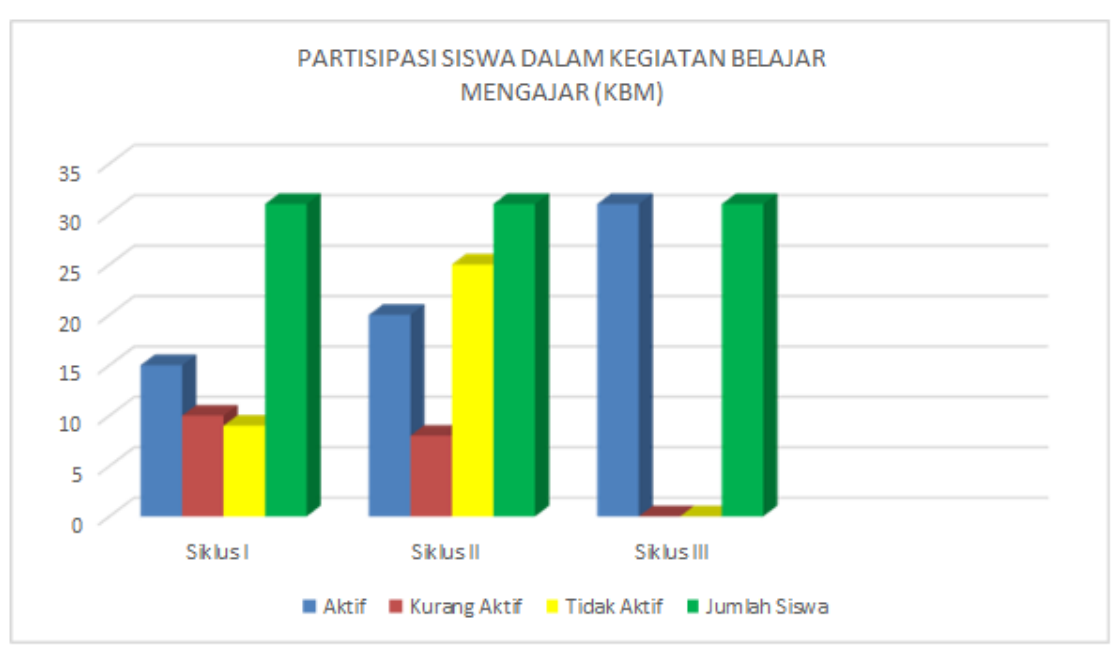

Tabel 2. Efektivitas Kelompok Siswa Dalam Kegiatan Belajar Membaca al-

Qur'an Pada Siswa Kelas XI Multimedia SMK Negeri 1 Mlarak Ponorogo

\begin{tabular}{|c|c|c|c|c|c|c|}
\hline \multirow{2}{*}{$\begin{array}{c}\text { Keterangan } \\
\text { Kelompok }\end{array}$} & \multicolumn{2}{|c|}{ Siklus I } & \multicolumn{2}{c|}{ Siklus II } & \multicolumn{2}{c|}{ Silkus III } \\
\cline { 2 - 7 } & $\begin{array}{c}\text { Jumlah } \\
\text { Kelompok }\end{array}$ & Prosentase & $\begin{array}{c}\text { Jumlah } \\
\text { Kelompok }\end{array}$ & Prosentase & $\begin{array}{c}\text { Jumlah } \\
\text { Kelompok }\end{array}$ & Prosentase \\
\hline Efektif & 4 & $40 \%$ & 6 & $60 \%$ & 10 & $100,0 \%$ \\
\hline Kurang Efektif & 3 & $30 \%$ & 3 & $30 \%$ & 0 & $0,0 \%$ \\
\hline Tidak Efektif & 3 & $30 \%$ & 1 & $10 \%$ & 0 & $0,0 \%$ \\
\hline Jumlah & 10 & $100 \%$ & 10 & $100 \%$ & 10 & $100 \%$ \\
\hline
\end{tabular}


Grafik 2. Efektivitas Kelompok Siswa Dalam Kegiatan Belajar Membaca alQur'an Pada Siswa Kelas XI Multimedia SMK Negeri 1 Mlarak Ponorogo

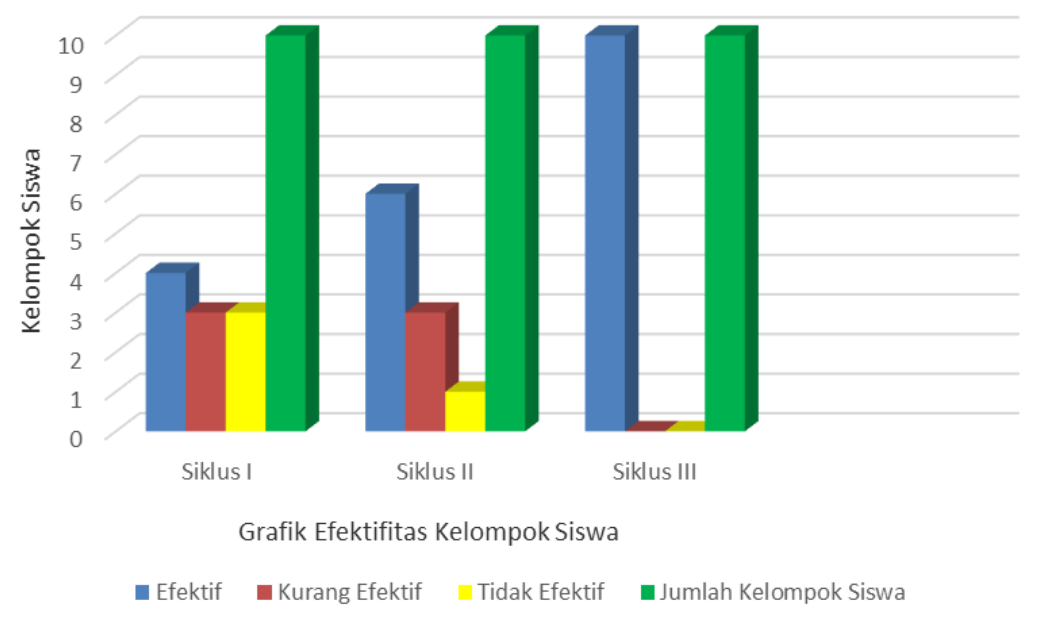

Tabel 3. Hasil Prestasi Belajar Siswa dalam Materi Membaca al-Qur'an

Pada Siswa Kelas XI Multimedia SMK Negeri 1 Mlarak Ponorogo

\begin{tabular}{|c|c|c|c|c|c|c|c|}
\hline \multirow{2}{*}{$\begin{array}{l}\text { Hasil } \\
\text { Belajar }\end{array}$} & \multirow[b]{2}{*}{ Nilai } & \multicolumn{2}{|c|}{ Siklus I } & \multicolumn{2}{|c|}{ Siklus II } & \multicolumn{2}{|c|}{ Silkus III } \\
\hline & & $\begin{array}{l}\text { Jumlah } \\
\text { Siswa }\end{array}$ & $\begin{array}{c}\text { Prosentas } \\
\text { e }\end{array}$ & $\begin{array}{l}\text { Jumlah } \\
\text { Siswa }\end{array}$ & Prosentase & $\begin{array}{l}\text { Jumlah } \\
\text { Siswa }\end{array}$ & Prosentase \\
\hline $\begin{array}{c}\text { Kurang } \\
\text { Sekali }\end{array}$ & $0-49$ & 7 & 22,58 & 3 & 9,67 & 0 & 0,0 \\
\hline Kurang & $50-69$ & 11 & 35,48 & 7 & 22,58 & 0 & 0,0 \\
\hline Cukup & $70-75$ & 9 & 29,04 & 11 & 35,48 & 14 & 45,17 \\
\hline Baik & $76-85$ & 4 & 12,90 & 6 & 19,35 & 9 & 29,04 \\
\hline BaikSekali & $\begin{array}{l}86- \\
100\end{array}$ & 0 & 0,00 & 4 & 12,90 & 8 & 25,80 \\
\hline \multicolumn{2}{|c|}{$\begin{array}{l}\text { Prosentase } \\
\text { Ketuntasan }\end{array}$} & $\begin{array}{r}\text { Tuntas } \\
(4 \\
\text { Tidak } \\
\text { Siswa }\end{array}$ & $\begin{array}{l}3 \text { Siswa } \\
3 \%) \\
\text { ntas: } 18 \\
8,07 \%)\end{array}$ & $\begin{array}{r}\text { Tunt } \\
\text { Tidak } \\
\text { Sisw }\end{array}$ & $\begin{array}{l}21 \text { Siswa } \\
74 \%) \\
\text { intas: } 10 \\
32,26 \%)\end{array}$ & $\begin{array}{r}\text { Tunta } \\
(10 \\
\text { Tidak } \\
\text { Sisw }\end{array}$ & $\begin{array}{l}31 \text { Siswa } \\
, 00 \%) \\
\text { untas: } 0 \\
(0,00 \%)\end{array}$ \\
\hline
\end{tabular}


Grafik 3. Grafik Hasil Belajar Siswa dalam Materi Membaca al-Qur'an Pada Siswa Kelas XI Multimedia SMK Negeri 1 Mlarak Ponorogo

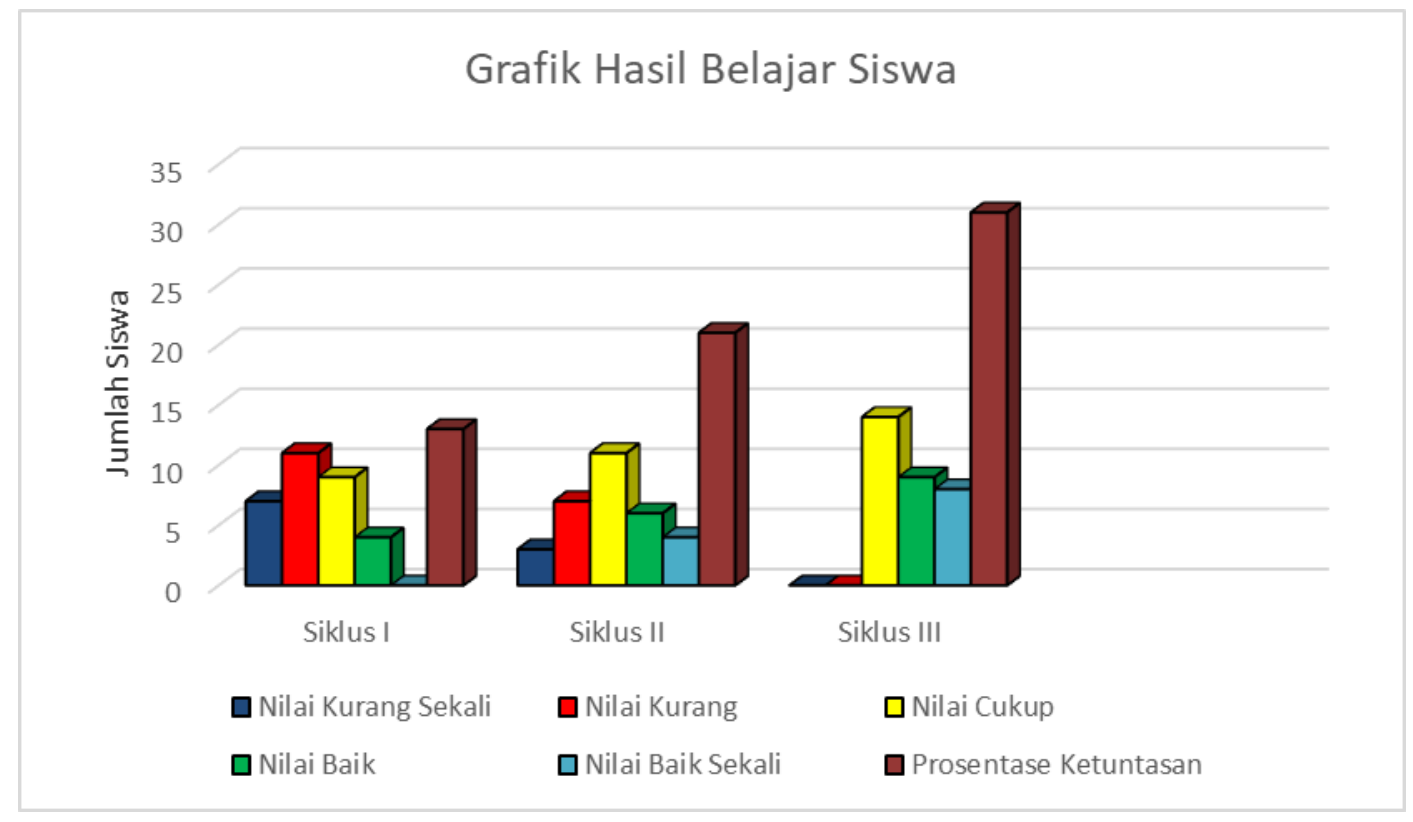

Tabel 4. Rekapitulasi Hasil Observasi Untuk Guru/Peneliti Kegiatan Belajar Membaca al-Qur'an Pada Siswa Kelas XI Multimedia SMK Negeri 1 Mlarak Ponorogo

\begin{tabular}{|c|c|c|c|c|}
\hline No & Indikator/Aspek Yang Dinilai & $\begin{array}{c}\text { Skore Siklus } \\
\text { Pertama }\end{array}$ & $\begin{array}{c}\text { Skore Siklus } \\
\text { Kedua }\end{array}$ & $\begin{array}{c}\text { Skore Siklus } \\
\text { Ketiga }\end{array}$ \\
\hline \multicolumn{5}{|c|}{ A. Pra-Pembelajaran } \\
\hline 1 & Pemeriksaan Kesiapan Siswa & 7,0 & 8,0 & 8,0 \\
\hline 2 & Pelaksanaan Kegiatan Apersepsi & 7,0 & 8,0 & 8,5 \\
\hline & & 14.00 & 16.00 & 16.50 \\
\hline \multicolumn{5}{|c|}{ B. Kegiatan Inti Pembelajaran } \\
\hline 1 & $\begin{array}{ll}\text { Penguasaan } & \text { Materi } \\
\text { Pembelajaran } & \end{array}$ & 7,5 & 8,0 & 8,5 \\
\hline 2 & $\begin{array}{l}\text { Kegiatan Materi dengan } \\
\text { Pengetahuan Lain }\end{array}$ & 7,0 & 8,0 & 8,5 \\
\hline 3 & $\begin{array}{lcc}\text { Penyampaian } & \text { Materi } & \text { dengan } \\
\text { Pengetahuan } & \text { lain } & \text { dengan }\end{array}$ & 7,5 & 7,5 & 8,5 \\
\hline
\end{tabular}




\begin{tabular}{|c|c|c|c|c|}
\hline & Hirarki Belajar & & & \\
\hline 4 & $\begin{array}{l}\text { Kaitan Materi dengan Realitas } \\
\text { kehidupan }\end{array}$ & 7,5 & 8,5 & 8,5 \\
\hline & & 30.00 & 31.50 & 34.00 \\
\hline C. $\mathbf{P}$ & ndekatan Strategi Pembelajaran & & & \\
\hline 1 & $\begin{array}{l}\text { Pelaksanaan Pembelajaran } \\
\text { sesuai dengan Kompetensi } \\
\text { (Tujuan) yang akan dicapai }\end{array}$ & 7,5 & 8,0 & 8,5 \\
\hline 2 & $\begin{array}{ll}\text { Pelaksanaan } & \text { Pembelajaran } \\
\text { secara Runtut } & \end{array}$ & 8,0 & 8,0 & 8,5 \\
\hline 3 & Penguasaan Kelas & 7,5 & 8,0 & 9,0 \\
\hline 4 & Konstektualisasi Pembelajaran & 7,5 & 8,0 & 8,0 \\
\hline 5 & $\begin{array}{lr}\text { Pembelajaran } & \text { yang } \\
\text { memungkinkan } & \text { Tumbuhnya } \\
\text { Kebiasaan Positif } & \end{array}$ & 7,5 & 8,0 & 8,0 \\
\hline 6 & Pemanfaatan Alokasi Waktu & 7,5 & 8,0 & 8,5 \\
\hline & & 45.50 & 48.00 & 50.50 \\
\hline D. $P$ & manfaatan Sumber Belajar/Medi & embelaj & & \\
\hline 1 & $\begin{array}{l}\text { Penggunaan Media secara } \\
\text { Efektif dan Efisien }\end{array}$ & 8,0 & 8,5 & 8,5 \\
\hline 2 & $\begin{array}{l}\text { Penyampaian Pesan yang } \\
\text { Menarik }\end{array}$ & 7,5 & 8,0 & 8,0 \\
\hline 3 & $\begin{array}{lrl}\text { Pelibatan Siswa } & \text { dalam } \\
\text { Pemanfaatan Media } & \end{array}$ & 7,5 & 8,0 & 8,0 \\
\hline & & 21.50 & 25.00 & 25.00 \\
\hline E. P & mbelajaran Yang Merangsang Da & emeliha & rlibata & \\
\hline 1 & $\begin{array}{l}\text { Menumbuhkan Partisipasi } \\
\text { Siswa dalam Pembelajaran }\end{array}$ & 7,5 & 8,0 & 8,5 \\
\hline 2 & Keterbukaan Sikap terhadap & 7,0 & 8,0 & 8,0 \\
\hline
\end{tabular}




\begin{tabular}{|c|c|c|c|c|}
\hline & Respon Siswa & & & \\
\hline 3 & $\begin{array}{l}\text { Penumbuhan Keceriaan dan } \\
\text { Antusiasme Siswa dalam Belajar }\end{array}$ & 7,5 & 7,5 & 8,5 \\
\hline & & 21.00 & 23.50 & 25.00 \\
\hline F. I & nilaian Proses dan Hasil Belajar & & & \\
\hline 1 & $\begin{array}{l}\text { Pemantauan Kemajuan Belajar } \\
\text { selama Proses }\end{array}$ & 7,5 & 8,0 & 8,5 \\
\hline 2 & $\begin{array}{l}\text { Penilaian Akhir sesuai dengan } \\
\text { Kompetensi }\end{array}$ & 7,5 & 8,0 & 8,0 \\
\hline & & 15.00 & 16.00 & 16.50 \\
\hline G. & enggunaan Bahasa & & & \\
\hline 1 & $\begin{array}{l}\text { Penggunaan Bahasa Lisan dan } \\
\text { Tulis secara Jelas, Baik dan } \\
\text { Benar }\end{array}$ & 8,0 & 8,0 & 9,0 \\
\hline 2 & $\begin{array}{l}\text { Penyampaian Bahasa dengan } \\
\text { Baik dan Sesuai }\end{array}$ & 7,5 & 7,5 & 8,0 \\
\hline & & 15.50 & 15.50 & 17.00 \\
\hline H. & enutup & & & \\
\hline 1 & $\begin{array}{l}\text { Refleksi atau Pembuatan } \\
\text { Kesimpulan yang } \\
\text { Siswa }\end{array}$ & 7,5 & 8,0 & 8,5 \\
\hline 2 & $\begin{array}{l}\text { Pelaksanaan Tindaklanjut } \\
\text { (Pemberian Arahan, Tugas dan } \\
\text { Remidi) }\end{array}$ & 7,5 & 8,0 & 8,5 \\
\hline & & 15.00 & 16.00 & 17.00 \\
\hline & Jumlah Skore & 177.5 & 191.5 & 201.5 \\
\hline & Nilai Rata-rata & 7.39 & 7.97 & 8.39 \\
\hline
\end{tabular}


Grafik 4. Kegiatan Guru dalam KBM Belajar baca al-Qur'an Pada Siswa XI Multimedia SMK Negeri 1 Mlarak Ponorogo

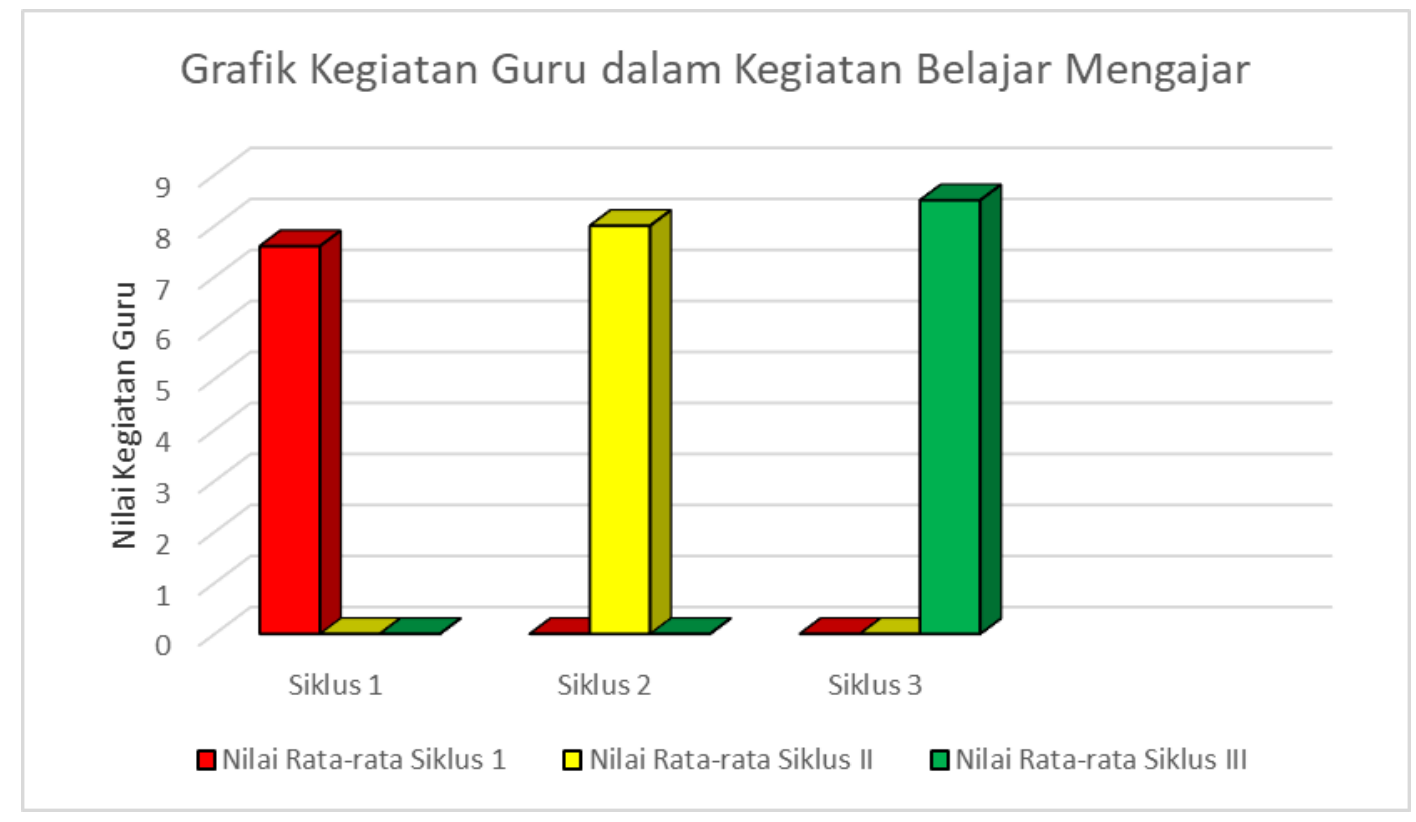

Proses analisis data dan pembahasan hasil penelitian setiap siklus meliputi peningkatan perilaku siswa efektivitas siswa hasil belajar siswa, dan hasil observasi guru dan peneliti dalam meningkatkan motivasi belajar baca al-Qur'an siswa melalui learning together technique of cooperative learning method di SMK Negeri 1 Mlarak Ponorogo, hasilnya dapat diuraikan sebagai berikut:

Pertama, pada siklus ini merupakan pembelajaran baca al-Qur'an melalui model pembelajaran learning together dilaksanakan pada hari Rabu 19 Agustus 2020 pada jam ke 5-6-7 yang dilakukan selama 120 menit. Dengan perincian 15 menit digunakan untuk persiapan, 75 menit pelaksanaan, 45 untuk diskusi, dan 15 menit untuk melaksanakan tes secara individual. Pembahasan pada siklus pertama, pada tabel 1, tabel 2, dan tabel 3, berdasarkan pengamatan observasi partisipasi dan perilaku siswa efektivitas kelompok dan motivasi belajar siswa kelas XI Multimedia dengan jumlah 31 siswa, maka dari tabel diatas dapat diuraikan sebagai berikut: (1) siswa kelas XI Multimedia SMK Negeri 1 Mlarak dalam partisipasi siswa mengikuti kegiatan belajar mengajar siswa aktif 14 siswa (45,16\%); siswa kurang aktif 9 siswa (29.04\%); dan siswa 
tidak aktif 8 siswa (25.80\%); (2) efektivitas kelompok belajar yang efektif terdiri dari empat kelompok (40,00\%); kelompok kurang efektif tiga kelompok (30,00\%); dan kelompok tidak efektif tiga kelompok (30,00\%); dan (3) hasil motivasi belajar siswa yang belajar tuntas 13 siswa (41,93\%); siswa yang belum tuntas 18 siswa (58.07\%). Berdasarkan uraian tersebut, keaktifan siswa dalam mengikuti kegiatan belajar mengajar keaktifan siswa pada siklus 1 kurang baik, efektivitas kelompok siswa dalam menerima pelajaran masih kurang. Siswa pada saat diberi tugas masih banyak menggantungkan jawaban pada teman yang dianggap pandai dalam kelompoknya. Bimbingan guru terhadap siswa baik secara individual maupun kelompok belum merata secara garis besar pelaksanaan siklus 1 berlangsung cukup baik tapi kurang kondusif.

Kedua, pada siklus ini dilaksanakan pada hari Rabu 26 Agustus 2020 pada jam ke 5-6-7 selama 120 menit, dengan perincian 15 menit digunakan untuk persiapan, 75 menit pelaksanaan membaca al-Qur'an pada surat al-Maidah ayat:48, surat an-Nisa' ayat:59, dan surat At Taubah ayat:105, melaksanakan diskusi 60 menit, sedangkan yang 15 menit untuk melaksanakan tes secara individual. Pembahasan pada siklus kedua, pada tabel 1, tabel 2, dan tabel 3, berdasarkan pengamatan/observasi partisipasi perilaku siswa efektivitas kelompok, dan motivasi belajar siswa kelas XI Multimedia dengan jumlah 31 siswa, maka dari tabel diatas dapat diuraikan sebagai berikut, bahwa: (1) siswa kelas XI Multimedia dalam partisipasi siswa mengikuti kegiatan belajar mengajar siswa aktif 20 siswa (64,52\%); siswa kurang aktif 8 siswa (25,80\%); dan sedangkan siswa tidak aktif 3 siswa (9,86\%). Pada siklus kedua ini, efektivitas kelompok belajar kelompok efektif 6 kelompok (60,00\%); kelompok kurang efektif tiga kelompok (30,00\%); dan kelompok tidak efektif satu kelompok (10,00\%). Hasil motivasi belajar siswa belajar tuntas 21 siswa $(67,74 \%)$; dan siswa yang belum tuntas 10 siswa (32,26\%). Berdasarkan uraian tersebut, keaktifan mengikuti kegiatan belajar mengajar, keaktipan siswa dalam siklus kedua cukup baik, kegiatan belajar sudah kondusif, efektivitas 
siswa dalam menerima pelajaran meningkat namun masih yang ada siswa yang menggantungkan pada teman sekelompok yang pandai karena masih ada sesuatu yang kurang percaya diri titik bimbingan guru terhadap siswa baik secara individual maupun kelompok sudah merata dan maksimal. Secara garis besar pelaksanaan siklus kedua berlangsung cukup baik dan cukup kondusif karena masih ada siswa yang belum tuntas maka kegiatan pada siklus kedua masih perlu diulang/dilanjutkan.

Ketiga, pada siklus ini dilaksanakan pada hari Rabu 2 September 2020 pada jam ke 5-6-7 selama 120 menit, dengan perincian 15 menit digunakan untuk persiapan, 15 menit untuk contoh membaca oleh guru, 75 menit pelaksanaan membaca siswa, dan 45 menit untuk melaksanakan tes pengetahuan secara individual. Pembahasan pada siklus ketiga pada tabel 1 , tabel 2 dan tabel 3, berdasarkan pengamatan/observasi partisipasi perilaku siswa efektivitas kelompok, dan motivasi belajar siswa kelas XI Multimedia dengan jumlah 31 siswa, maka dari tabel diatas dapat diuraikan sebagai berikut: siswa kelas XI Multimedia dalam partisipasi siswa mengikuti kegiatan belajar mengajar siswa aktif 31 siswa mencapai $100 \%$, dan siswa kurang aktif dan tidak aktif 0 siswa mencapai $0,00 \%$. Pada siklus ketiga ini, efektivitas kelompok belajar kelompok efektif 10 kelompok mencapai 100,00\%, dan kelompok kurang efektif dan tidak efektif tidak ada 0 kelompok mencapai $0.00 \%$. Hasil ketuntasan belajar baca al-Qur'an 31 siswa mencapai $100.00 \%$, dan tidak ketuntasan belajar baca al-Qur'an 0 siswa mencapai $0.00 \%$. Berdasarkan uraian tersebut, dalam kegiatan belajar mengajar keaktifan siswa pada siklus ketiga dalam kegiatan belajar telah berjalan dengan kondusif dan siswa mampu mengerjakan tugas, sehingga tidak tergantung pada teman. Titik bimbingan guru terhadap siswa, baik secara individual maupun kelompok sudah merata dan maksimal. Secara garis besar pelaksanaan siklus ketiga berlangsung dengan baik dan sangat kondusif. Ketuntasan belajar siswa telah mencapai 
$100 \%$ dalam siklus ini semua siswa sudah belajar tuntas, maka tindakan siklus ketiga dihentikan.

\section{KESIMPULAN}

Berdasarkan hasil penelitian yang telah dipaparkan pada tiga siklus diatas, hasil penelitian, dan pembahasan yang telah dilakukan oleh peneliti, maka dapat disimpulkan bahwa: (1) learning together technique of cooperative learning method telah mampu meningkatkan mutu pembelajaran siswa kelas XI dalam mata pelajaran pendidikan agama dan budi pekerti di SMK Negeri 1 Mlarak Ponorogo; (2) learning together technique of cooperative learning method memiliki dampak positif dalam meningkatkan motivasi belajar siswa kelas XI yang ditandai dengan peningkatan ketuntasan belajar siswa di SMK Negeri 1 Mlarak Ponorogo, yaitu: siklus pertama (41,93\%); siklus kedua (67.74\%); dan siklus ketiga (100\%); (3) learning together technique of cooperative learning method telah meningkatkan kepercayaan diri siswa kelas XI, dikarenakan mereka mendapatkan perhatian dan kesempatan untuk menyampaikan pendapat dan pertanyaan; (4) siswa dapat bekerja secara mandiri maupun kelompok serta mampu mempertanggungjawabkan segala tugas individu maupun kelompok; dan (5) penerapan learning together technique of cooperative learning method mempunyai pengaruh positif untuk meningkatkan motivasi belajar siswa dalam membaca al-Qur'an.

\section{BIBLIOGRAFI}

[1] Andini, A. D. (2019). Metodologi kitab tafsir ul Quran: translation and commentary of the holy Quran karya Maulana Abdul Majid Daryabadi. UIN Sunan Ampel Surabaya.

[2] Anwar, S. (2021). Internalisasi Nilai Pendidikan Akhlak dalam Surat AlHujurat Tafsir fi ZIlalil Qur'an. JIE: Journal of Islamic Edication, 6(1), 112. 
[3] Arsyad, A., \& Salahudin, S. (2018). Hubungan Kemampuan Membaca Al Qur'an dan Minat Belajar Siswa dengan Hasil Belajar Pendidikan Agama Islam (Pai). Edukasi, 16(2), 294352.

[4] Aryati, A., Azizah, N., \& Hazmin, H. (2020). Pengaruh Hafalan Al-Qur'an terhadap Prestasi Belajar Bahasa Arab Siswa. JOEAI: Journal of Education and Instruction, 3(1), 75-84.

[5] Ashari, R. (2017). THE METHOD OF MORAL EDUCATION IN CONSTRUCTING PERSONALITY ACCORDING TO ISLAM. AL-ASASIYYA: Journal Of Basic Education, 2(1).

[6] Ashari, R., Syam, A. R., \& Budiman, A. (2017). The World Challenge Of Islamic Education Toward Human Resources Development. Proceeding International Conference on Islamic Education (ICIED), 169-175.

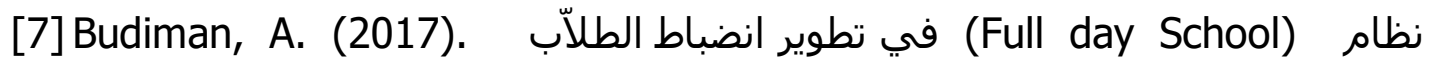
المدرسة على المنهج المتكامل. Educan: Jurnal Pendidikan Islam, 1(2).

[8] Budiman, A., \& Ismatullah, F. (2016). Penerapan Pendidikan Akhlak di Sekolah Menengah Pertama Islam Terpadu Darut Taqwa Jenangan Ponorogo Tahun Ajaran 2014-2015. At-Ta'dib, 10(1).

[9] Dalimunthe, R. A. (2020). Minat Siswa Mengikuti Pesantren Kilat di SMK Negeri 1 Pantai Labu Tahun 2019. Fitrah: Journal of Islamic Education, $1(1), 158-169$.

[10] Fahri, H. (2020). Al-Quran dan Keautentikannya; Kajian tentang Rasm Al-Qur'an dalam Mushaf Uthmani. Al Hikmah: Jurnal Studi Keislaman, $10(2), 141-154$.

[11] Ghony, M. D. (2008). Penelitian Tindakan Kelas. UIN-Maliki Press.

[12] Hidayat, M. C., \& Syam, A. R. (2020). Urgensitas perencanaan strategis dan pengelolaan sumber daya manusia madrasah era revolusi industri 4.0. AL-ASASIYYA: Journal Of Basic Education, 4(1), 1-13. https://doi.org/10.24269/ajbe.v4i1.2100

[13] Hitami, M. (2012). Pengantar Studi Al-Qur'an: Teori dan Pendekatan. LKIS PELANGI AKSARA.

[14] Huberman, M., \& Miles, M. B. (2002). The qualitative researcher's companion. Sage.

[15] Husna, N. A., Jalil, A., \& Dewi, M. S. (2020). UPAYA GURU PENDIDIKAN AGAMA ISLAM DALAM MENINGKATKAN KEMAMPUAN BACA TULIS ALQUR'AN SISWA SMK YPM 12 TUBAN. Vicratina: Jurnal Pendidikan Islam, $5(4), 22-28$. 
[16] Ikhwan, A. (2014). Integrasi Pendidikan Islam (Nilai-Nilai Islami dalam Pembelajaran). Ta'allum: Jurnal Pendidikan Islam. https://doi.org/10.21274/taalum.2014.2.2.179-194

[17] Ikhwan, A. (2016). Manajemen Perencanaan Pendidikan Islam (Kajian Tematik Al-Qur'an dan Al-Hadist). EDUKASI: Jurnal Pendidikan Islam, 4(1), 128-155.

[18] Ikhwan, A., Farid, M., Rohmad, A., \& Syam, A. R. (2020). Revitalization of Islamic Education Teachers in the Development of Student Personality. 1st Borobudur International Symposium on Humanities, Economics and Social Sciences (BIS-HESS 2019), 162-165.

[19] Ikhwan, A., Noh, M. A. C., \& Iman, N. (2020). IMPLEMENTATION OF THE TAHFIDZAL-QUR'AN CURRICULUMAT THE TAHFIDZ MALAYSIA BOARDING SCHOOL. Journal of Critical Reviews, 78), 866-870.

[20] Jaya, S. A. F. (2019). AL-QUR'AN DAN HADIS SEBAGAI SUMBER HUKUM ISLAM. JURNAL INDO-ISLAMIKA, 9(2), 204-216.

[21] Kemmis, S., McTaggart, R., \& Nixon, R. (2013). The action research planner: Doing critical participatory action research. Springer Science \& Business Media.

[22] Khasinah, S. (2013). Classroom action research. PIONIR: Jurnal Pendidikan, 4(1).

[23] Laila, I. (2014). Penafsiran Al-Qur'an Berbasis Ilmu Pengetahuan. Epistemé: Jurnal Pengembangan IImu Keislaman, 9(1), 45-66.

[24] Maghfiroh, F., Sholikhah, H. A., \& Sofyan, F. A. (2019). Upaya Guru dalam Mengatasi Kesulitan Belajar Membaca Siswa. JIP (Jurnal IImiah PGMI), 5(1), 95-105.

[25] Masruroh, L. (2018). STUDI KOMPARASI ANTARA METODE KONVENSIONAL DAN METODE KLASIKAL TERHADAP KEBERHASILAN MEMBACA AL-QUR'AN. JIE (Journal of Islamic Education), 3(1).

[26] Muhammad, D. H. (2019). UPAYA PENINGKATAN BACA TULIS ALQURAN MELALUI METODE QIROATI. JIE (Journal of Islamic Education), 3(2), 142-162.

[27] Mujiono, M., Kurnianto, R., \& Setiawan, W. (2017). MENINGKATKAN HASIL BELAJAR AL-QUR'AN HADIST MELALUI PENERAPAN METODE CARD SORT PADA POKOK BAHASAN SURAT AT-TIN BAGI SISWA-SISWI KELAS III MI MA'ARIF PANJENG JENANGAN PONOROGO SEMESTER GENAP TAHUN PELAJARAN 2016-2017. TARBAWI: Journal on Islamic Education, 1(01). 
[28] Musodiqin, M., Nadjih, D., \& Nugroho, T. (2017). Implementasi Sorogan Dalam Pembelajaran Al-Qur'an Pada Madrasah Diniyah Takmiliyah. Ulumuddin: Jurnal IImu-IImu Keislaman, 71), 59-71.

[29] Nata, H. A. (2016). Pendidikan dalam perspektif Al-Qur'an. Prenada Media.

[30] Rochelle, S. (2019). Encountering the "Muslim": Guantánamo Bay, Detainees, and Apprehensions of Violence. Canadian Journal of Law \& Society/La Revue Canadienne Droit et Société, 34(2), 209-225.

[31] Sumaryanti, L., Syam, A. R., \& Syukroni, A. (2020). Urgency of implementing adab for students of elementary school in the perspective of the Qur'an and hadith. AL-ASASIYYA: Journal Of Basic Education, 5(1), 1-12.

[32] Svensson, J. (2017). Hurting the Qur'an--Suggestions Concerning the Psychological Infrastructure of Desecration. Temenos-Nordic Journal of Comparative Religion, 53(2), 243-264.

[33] Syam, A. R., \& Mukhlas, M. (2019). The Role of The Security Department In Regulating The Discipline of Members of Student Organizations in Darussalam Gontor Modern Islamic Institution. AtTa'dib, 14(1), 90. https://doi.org/10.21111/at-tadib.v14i1.2647

[34] Syam, A. R., Supriyanto, A., \& Mustiningsih, M. (2020). Democratic Leadership and Decisions Making on Education in Islamic Perspective. Cendekia: Jurnal Kependidikan Dan Kemasyarakatan, 1(1), 33-47.

[35] Syam, A. R., Ulfatin, N., \& Maisyaroh, M. (2020). Strategy for Establishment Santri Leadership Character. Istawa: Jurnal Pendidikan Islam, 5(1), 39. https://doi.org/10.24269/ijpi.v5i1.2197

[36] Yanggo, H. T. (2018). AL-QUR'AN SEBAGAI MUKJIZAT TERBESAR. MISYKAT: Jurnal IImu-IImu Al-Quran, Hadist, Syari'ah Dan Tarbiyah, 1(2), 1. 